\title{
幼児の知覚一運動経験が知的能力に及ぼす影響
}

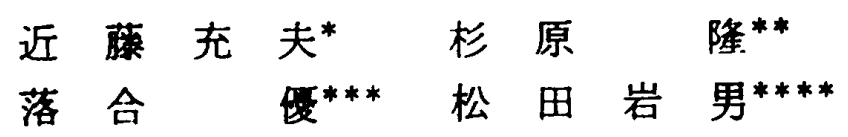

(昭和51年 3 月 5 日 受付)

\section{Effects of Perceptual-Motor Activity on Intellectual Ability of Pre-School Children}

\author{
Mitsuo Kondo \\ Takashi Sugihara \\ Masaru Ochiai \\ Iwao Matsuda
}

(Tokyo Gakugei University)

(Tokyo University of Education)

(Yokohama National University)

(The University of Tsukuba)

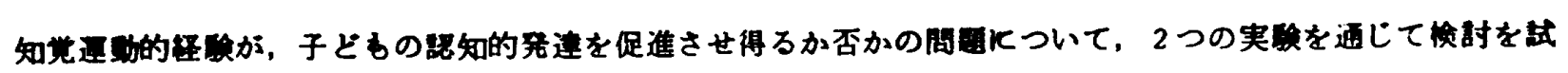
みた。

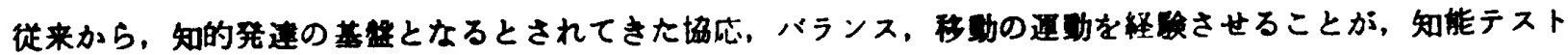

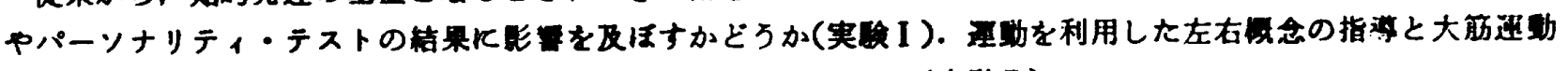

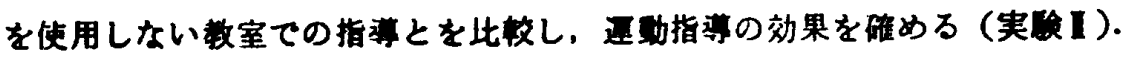

以下に桔果を栝括する。

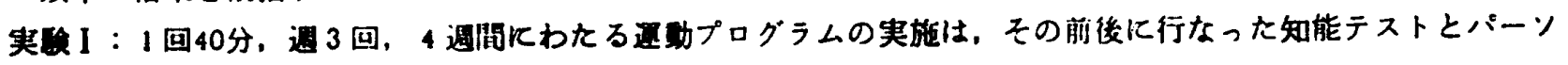
ナリティ・テストのいร゙れにも眨電を与えなかった。

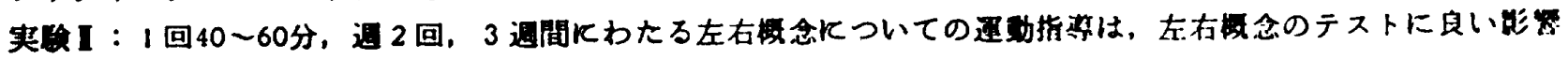
を与え，その効果は，室内指递とほほ同等であった。

\section{Summary}

Whether perceptual motor program could enhance the intellectual development of children or not was examined.

In the first experiment, five-year-old children participating in the motor program which involved balancing, co-ordination and locomotion were compared with the control group. The motor program - carried out for $40 \mathrm{~min}$. per a session, 3 sessions per a week, during 4 weeks-had no effect on the post-test scores of intelligence and personality tests.

In the second experiment, four-year-old children being taught right-left discrimination through motor activities were compared with the children taught by ordinaly in-door method and with the control group. The motor program-carried out for $40-60 \mathrm{~min}$. per a session, 2 sessions per a week, during 3 weeks-improved significantly in the right-left discrimination test as well as the children who took the ordinary in-door program. (Mitsuo Kondo, Takashi Sugihara, Masaru Ochiai, Iwao Matsuda: Effects of Perceptual-Motor Activity on Intellectual Ability of Pre-School Children. Jap. J. Phys. Educ., Vol. 21, No. 3, August, 1976, pp. 155 163)

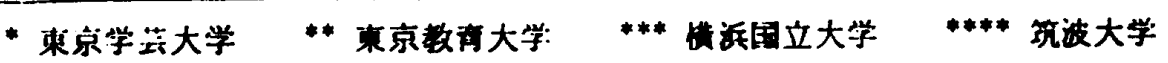




\section{風}

運動発達と認知的能力の発達との関速について は，運動能力テストの得点と学業成綪むるいは知 能テストなどの得点との相関係数を問題にすると いうかたちで，非常に多くの研究がなされてき た（こ扎らの研究は，松井 1962，B. Knapp 1963,加賀1968, J.B. Oxendine 1968, R.N. Singer 1968，およで A.H. Ismail 1969 らによって概镜 されている）しかしながらこのよ5な方法で は，たとえ相関が認められたとしても，両者の間 に生育環境や遗伝といった第 3 の介在变数が閣与 している可能性が十分考えられること，どちらが 原因でどちらが結果かについては何むわからない こと，さらには，運動発達と認知的発達の間に直 線的な関係が成り立つことが必ずしも想定できな いこと，などの理由により，両者の本啠的な関係 を解明するにははど薏いといわねばならない。

また，従来の発连研究の多くは，心身の種々の 頒域か年龄とともにどのように変化してゆくのか

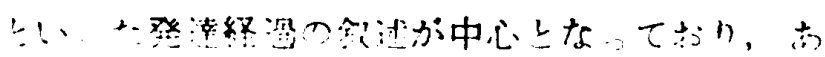
る発達琴皇がいかなる要因によってとのように規 定されるのかとい5因果関係の解明はきわ的て不 十分であった。このことは，本研究でとりあげた 認知的発達に新いて運動経験かどのよ5な役割を 果しているのかという問題についても例外ではな い. 運動と認知的発達を関連つけて説明しょ5と する理論は，何人かの研究者によって提出されて はいるものの，その多くは十分精密な理論とはい、 いがいし，また，それらの理論を実証的に㭘証 しょ5とする研究はごくわずかにすぎない（B.J. Cratty 1972, J.M. Fleming 1972, D.V. Harris 1973).

運勤経検を認知的発逢を規定する要因として位 胃づる理論は，両者の関連のし方とい5観点か ら大きく3つに大別できよ5（松田・杉原 1973）.

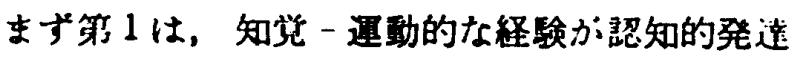
のための重要な基盤になっており，認吅的な能力 は知览一連動機能から分化発或してくると立张す る.この立場は，たとえばJ. Piaget (1960)の出 党運動的知能, D.O. Hebb (1949) の一次学習, N.C. Kephart（1964）の知党世界之行動世界の
対芯, C.H. Delacato (1966) の Neurological Organization の上5な認知的能力が発生し, 発攸 していく過程の中で，知筧一運协的な経験が中心 的な役割を果すことによって形成される前提条作 を热定する。

これに対して，第 2 の立場は，運動の遂行には 知的活動が随伴することを強調し，運動を経験す ることがそこに含まれている認知的能力の発達を 促進すると考える，つまり，運動の順序を憶える ことによって記憶力か，们数を数えたりすること によって数量の概念が形成されると仮定する。こ の立塨をとる研究者には，B.J. Cratty (1971) ゃ J.H. Humphrey (1970) p M. Frostig (1970) 5 がいる.

第 3 の立場は基本的には第 2 の立場と同様の考

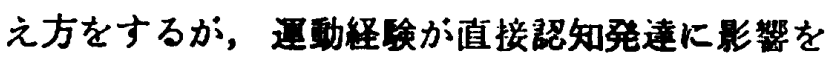
与えるのではなく，知的能力を発揮するために必 要とされる非知的要因，たとえば注意の集中力， 自己統制力, 社会的・情緒的適応なとの向上を引 き起し，その結果認知的能力か十分発揮されるよ

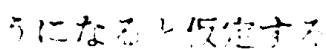

以上の分類は，子どもの認知的発達を促進する ためにどのような国動経験を与えれぱよいかを問 題にする時，非常に重要な視点を与える．第1の

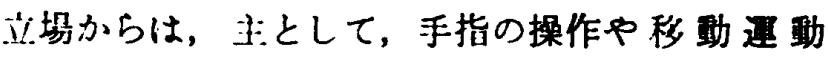
や，視觉を中心とする各程の感党と身体の桖々の 部分の弨応運動などが必要であるとされる。そし て，個々の運動は，特定の認知的能力と結びっく とは考えられていない.これに対して，第 2 の贞. 垬からは，運動の場の中に含まれている知的活動 を強調したり，また，意困的に知的な活動を運動 の場の中にとり入れて知的なかかわり合いをむた せる速動が提案される。

運動経験が子どもの知的発達にどのよ5な影製 を与えるかを実験的な手法に上っこ解明しょ5と

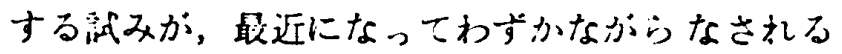

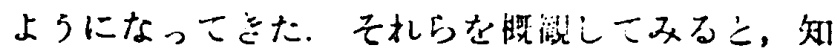
的な発進に問题をもつ対路については㔯定的な結 果を報告しているものもあるか（W.C. Chasy and W.Wyrick 1970, 松罒・杉原 1973), 運動の効果 が誌められている研究が多い（J.N Oliver 1958， W.O. Corder 1966, C.C. McCormick et al. 
1968，松田・杉原 1973).一方，普通児を対象とし た研究では，肯定的な結果を見出している研究は 見当らない，たとえば，小校 1 年生について， 6 か月間の Kephart-type の身体活動と伝統的な 体育の効果を比較した C. O’Connor (1969) は,前 者は迅野能力では後者より大きな進步をるたらし

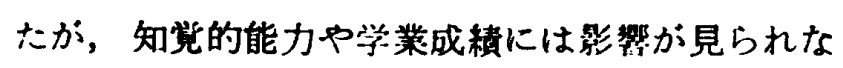
ふったと報告している。すた，邚筧一運動トレー ニングを週 3 日7か月間 Montessori preschool children に実施した C.C. McCormick とJ.N. Schnobrich (1971) む，対照样との間に有意な IQ の向上を見出していない，さらに，K. A. Leithwood とW. Fowler (1971) は4 歳巟に 4 か月 間の体操と音楽のトレーニングを行なったが，そ れらが一般知能に影製を与えないとい5 結果を得 ている、これらの研究，特に普通児を対象とした 研究は，非常に数が少なく，またこれまでに論 してきたよ5に、どよ5にして運䡃経験が知的 発達に影然を与えるのかを十分明確にしていない ために，とりあけられている運動の内容にむ問题 のあるものが多い.

\section{目的}

そこで本研究では，先に第 1 と第 2 の访坋とし こ汱ベられた理論をとりあげ，比較的短期間に集 中して与えられる知莫 - 遇動释験か，幼览の知的 発達を促進するかとうかを明らかにする目的で実 験が部面された。

つまり，実験 Iでは，多くの研究者によって知

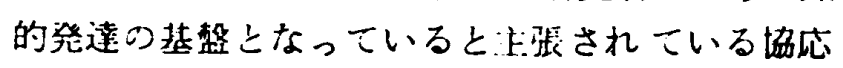
運動, ハシランスの運動，移動運動が知能テストの 得点を活上させるかどうかを，連動能力の発蓬の 水草という観点から分析する目的で実倹が計面さ れた。 また，同時に，ハーンナリティの変容を特 に意困して行なわない運動の䋂験がパーソナリテ

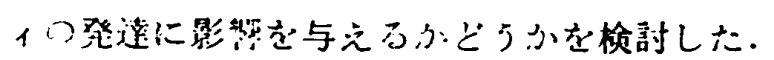

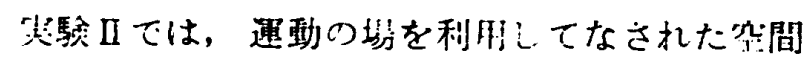

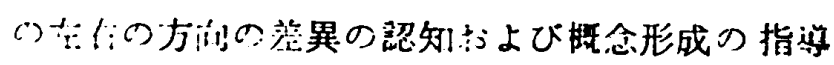

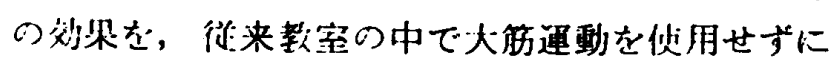
な吉机てきた指等方泣との此較に就いて明らかに

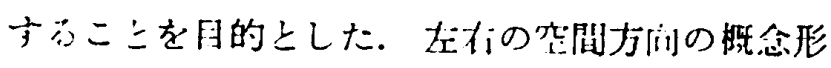

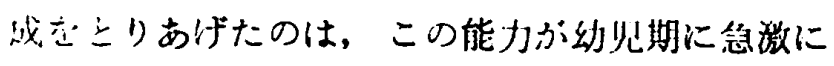

発達することと（勝井 1971），荲䡃と強い結びつ きをもつことを考猎したからである。 また，指導 効果の持続と日常の経験との交互作用をみるため に，指遭直後だけでなく，半年後の効果を㭘讨す ることにした。

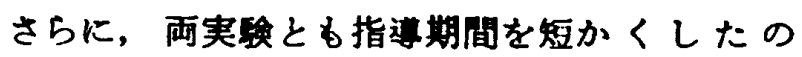
は，この種の実検で珫制することが非常に困制 な, 幼稚圆や家庭生活による多くの剩余変数の効 果を少しでる小さくすることを意四したという理 由による。

\section{方法と結果}

\section{1. 実䫱 I}

1) 実碒期間

昭和 48 年 4 月 6 月

2) 対象

2 つの都内私立幼稚園の 5 歳児クラスの各な 1 つを実馀群 (80名) と対照群（79名）に割り当て た.

\section{3）手続き}

すべての対象に，知能テスト，パーンナリティ ・テスト，運動能力テストを，約1か月を隔てて 前後 2 回実施した。実験群に対しては，1回約40 分週 3 回 4 週間にわたって後述する運動ブログラ ムが指莩された。この間, 対照群は通常の保育活 動がなされただけである。

4) テスト

（1）知能テスト 対象が幼児であること，知能の 水草が運隹と関連をむつと考えられることから， 知能が動作性 IQ, 言語性 IQ, 全検査 IQ と分析 的に测定できるWISC 知能診断検查を採用し た.

(2) パーソナリティ・テスト 子どむから直接反 応を得ることができ，しかも謤境によって形成さ れる行動傾问を测定することができるものとい5 こ亡を考出し，子どすに桧を見せて啠問しその反 応をロ江するとい5形式をとる太郎・花子テスト を用いた。

(3) 連動能力デスト指莩する最動プログラムの 内容を夹えて，以下の6 種目を運動能力テスト上 しこ之りあげた。(1)閉眼つま先圤ち (時間)，(2) ランスレイル歩き(歩数)，(3)゙ール受け (個数)， 
(4)まりつき(回数)，(5再足連続とび越し(時間)， 6立ち覀とび（距鹤）

5）国协プログラム

连助ブログラムには次のよ5なるのが含まれ， 2 2人の指造者のもとで実施された。

（1）平均台を使った进功 平均台は長さが $3 \mathrm{~m}$ 幅が $10 \mathrm{~cm}$ と $5 \mathrm{~cm}$ ，高さが $30 \mathrm{~cm}$ と $40 \mathrm{~cm}$ に変 化させることができるるのを用いた，具体的な活 地としては，前方・側方・後方への歩行，シャン プターン，4つ足步き，障害物のくぐり抜け・ま たぎ越し，とび乗り，とび降り，乗り越えなどで ある.

（2）大型䖽木を使った遇功 汒方体，㨁方体，三 角柱の板型や枠形の大型稜木を様々な的序や形態 にならベて，連続的なとび越し，とび乗り，とび 移り、シクザグ走，ケンケン，トンネルくぐクな どの国怔が行なわれた。

（3）ボールを使った堇功 上述の平均台と積木を
用いた運功をする時に、ボールを持ったり，つい たり，投げたり，受けたりする罣動が付加され た.

6) 結果

正轨指䢖の内容は，ハランスを含む全身的な協 心国功を経検する機会を持たせることを意四して 楼成したものであり，必ずしも直接運怔能力を高 めることを机らったわけではないしかしなが ら，その結果か遇動能力の向上にどの程度䦛与し たかを明らかにしておくことは，運動指導が知能 やパーソナリティにどのよ5な効果を与えたかを 考察する場合に当然考监する必要がある。こ でまず，通峌能力テストの結果について検討を

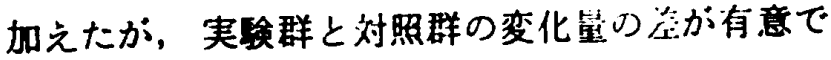
あったのは，男女とも両足連続とび越し 1 種日に すぎなかった $(P<0.01)$.

WISC 知能診断検备の結果を表 1 に示した。

pretest と posttest の変化量は，奏験群男子の

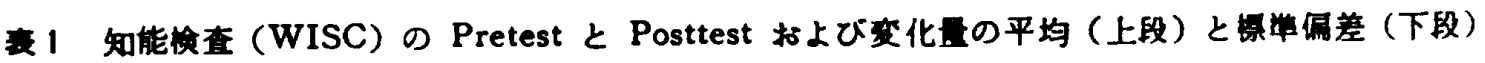
男子

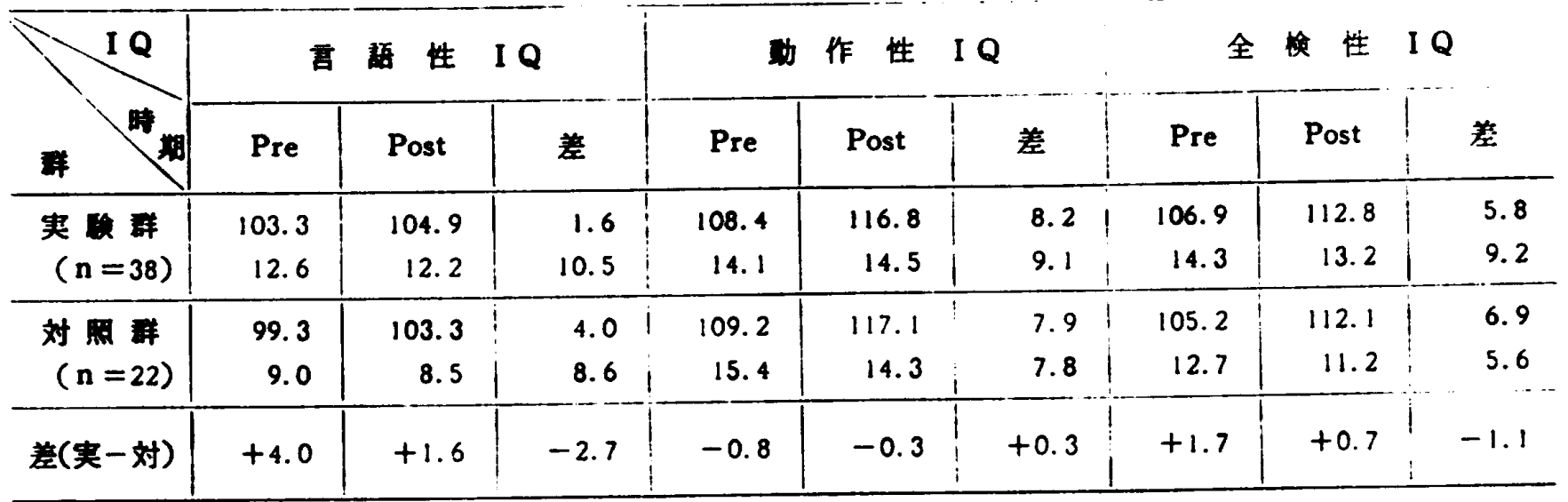

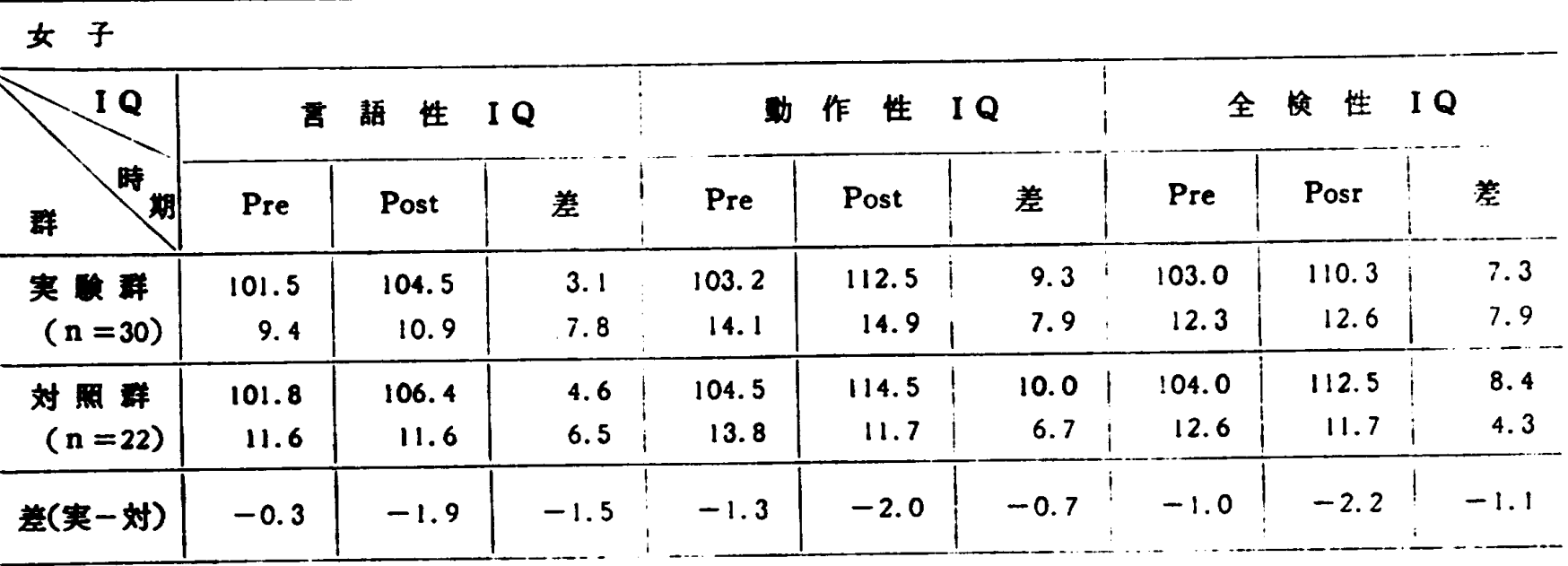


言語性 I Q 除いて，他はすべて posttest の方が 有意に高くなっている，しかしながら，実験群と 対照群の変化量の差はすへて有意ではない。した がって, posttestにおける IQ の向上は, 知能テ ストの繰り返しによる履歴勃果 (career effect) であると考えられる. 次に，遇動能力の水隼によ 。て運娌経跧が知能の向上に与える効果が異るか どうかをみるために, pretest の还栺能力テスト の成䌙により高・中・低の3つの逐動能力群に分 け，I Qの変化量の比較を試みたが，一定の傾向 はみられなかったささらに，知能の水䇠により運 功经検の影整が異るかどかをみるために， pretestの知能テストの成績により高・中・低の 3 つの知能群に分け，IＱの変化量を比较したとこ ろ,この場合も一定の傾向はみられなかった。

太郎・花子テストは，数量化できる「独汒一传 存」,「活韧性大一活野性小」, 「あたたかい一つめ たい」，「反抗的一说順」の 4 つの尺度について検 討を加えたか，いすれす pretestと posttest の変 化量および実硢群と対照群の変化量の差は非常に 小さく，军動指遭がハ・ーソナリティ・テスト得点 に影要を与えた之みられる徽侯は認められなかっ た.

\section{2. 実鈋 II}

\section{1）実跧期間}

昭和48年10月～昭利149年11月

2) 対象

都内の私立幼稚園に在圆する 4 歳坚の3クラス を，迹功指莩群，室内指導群，対照群に割り当て た. 所定の実験手続きをすべて受けた対象は，運 功指望群22名，室内指等群29名，対周群29名の合 計80名であった。

\section{3) 手続}

上記の 3 群のすバてについて，方向諰知のテス トが指遷プログラム（3 週間）の前後とおよそ半

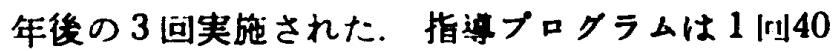

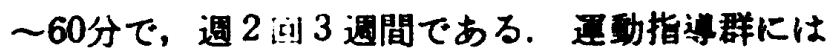

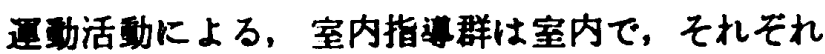
指息を受け，対照群にはその間通常の保青活動か～ なされた，2回目の方向范知のテスト (posttest 1) 以後の半年間は，3 群とも通常の保青を受け た.

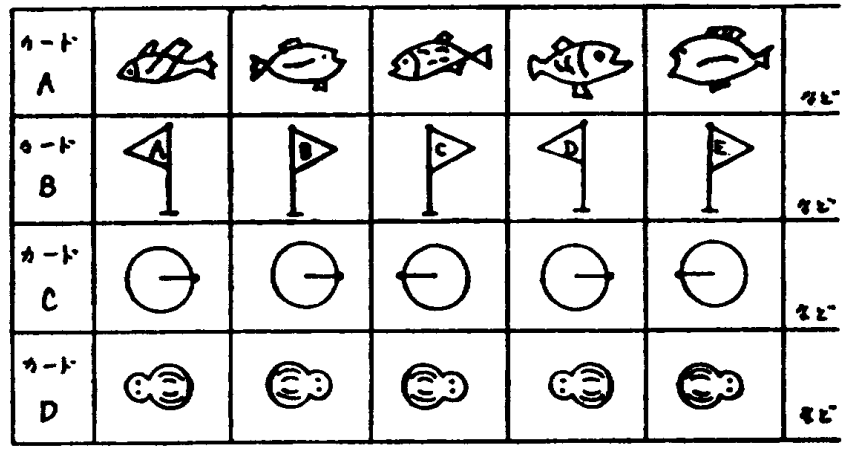

図1左右分類課題に使用した四形の的

\section{4）方向思知のテスト}

腾井（1971）加因形分類に方ける上下左右柩念 と，空間方向に関する言語概念の発達的分析で用 いた方法の一部を，はほそのまま用いた。

（1）自己身体の左石指示 先端を赤く如た長さ $30 \mathrm{~cm}$ の棒を持たせ，「不（左）上いうのはどっち の方ですか，この棒でまっすぐ们（左）の方を指 して下さい」とい5教示を与えて反応させた，努 勢は立位と仰臥位で，左右とも正しく指示した場 合を正答とした。

（2）困形分類 们あるいは左を问いた四形各 5 枚 ずつ計10枚をランダムな配列で子どるの前になら ヘ，「同じものどうし，お仲閏どうし壮分ずつに 分けて下さい」と指示する. 困形は 4 組あり（図 1 を参照のこと)，C・Dの 2 組は10收の困形の形 墛はまったく同じで方问の差異だけが分類の手が かりとなるのに対し， A・Bの 2 租は10枚の形热 6異なって抢り，左右の方向性を抽出する能力， つまり，左不の方向の概念が必要之される。

5）指遭ブログラム

（1）連動指或 下記の3 種の運動あそびの中で， 方向の差異の認知（目標物につけられた目所方乎 かかりとして方间を区別する）一方向の非言詻 的概念（目盺なしでこちら側，あちら側とい5淁 現と指迺者の手による指示で方闪を区別する） 一言語䀧念と心結合（手による指示と“みき”

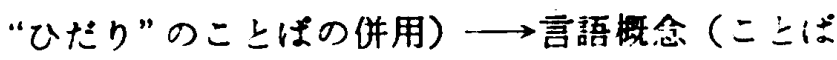
たけで左不を区別する）の4つの段階をふんだか たちで，左右の方向概念の形成を意困した指埒か なされた。

(1)とび箱を使った速怔：いろいろなとび箱进功 をしたあとで右あるいは左側に回ってるとの位蜀 
へもどらせる. (2) 旗鬥を使った運動：1〜2 mの 間隔でつくられた旗門をいろいろなやり方で右あ るいは左に通り拔けさせる。（3)マットを使った迋 動：指遭者のまわりに正方形の枠をつくるよ5に 並らべた 4 枚のマットの上でいろいろなマット遇 動をさせるが，この時どのマットを使らかを指導 者が指示する.

（2）室内指遭 以り桧，図形カード，人形，而单 な道路の四と切り抜いた自動事，歌を利用して， 運動指这左右の判断の回数ができるだけ等しく なるように，左朽方问の概念形成を意困した指迤 を行なった。

6) 結果

(1) 向上率について

pretest で正しく答えられなかったものの5ち 何\%が posttest 1 で正しく答えられるようにな ったか, また, posttest 1 で正しく答えられなか ったものの5ち何\%が posttest 2 で正しく答え られるようになったかといら向上車を算出したも のを表 2 と 3 に示した.

表 2 Pretestと Posttest |の間の向上䩚1)

$\%$ ( ) 内人数

\begin{tabular}{|c|c|c|c|c|}
\hline \multicolumn{2}{|c|}{ 項目 } & \multicolumn{2}{|c|}{ 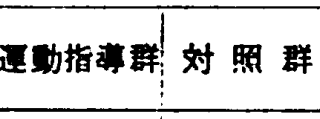 } & 室内指营群 \\
\hline \multirow{2}{*}{$\begin{array}{l}\text { 自己身 } \\
\text { 右の左 } \\
\text { 右 }\end{array}$} & 立 位 & $70(7)$ & $50(6)$ & $70(7)$ \\
\hline & 仰 卧 位 & $50(6)$ & $43(6)$ & $33(4)$ \\
\hline \multirow{3}{*}{ 详 } & カ $-\boldsymbol{F}^{\prime} \mathrm{A}$ & $19(4)$ & $12(3)$ & $16(4)$ \\
\hline & 力 $-F^{\prime} B$ & $25(5)$ & $12(3)$ & $29(7)$ \\
\hline & 力 $-\mathrm{HC}$ & $25(4)$ & $19(5)$ & $25(5)$ \\
\hline 分 & カ - F'D $^{\prime}$ & $29(5)$ & $17(4)$ & $36(8)$ \\
\hline \multirow[t]{2}{*}{ 䅡 } & 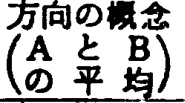 & 22 & 12 & 23 \\
\hline & 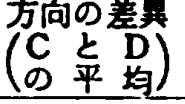 & 27 & 18 & 31 \\
\hline
\end{tabular}

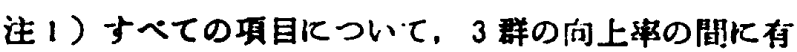
意差なし。

pretest と posttest 1 についてみると，建動指 望群は対照群よりすへてての項目について高い向上 事を示している，特に，立位での自己身体の左右 指示は，運動指迸群の方が対照群よりそれそれ20
㤗 3 Posttest |と2の間の向上率洁2？

$\%$ （）内人数

\begin{tabular}{|c|c|c|c|c|}
\hline \multicolumn{2}{|l|}{ 項目 } & 是動指票群 & 対 照 群 & 室内扰 \\
\hline \multirow{2}{*}{$\begin{array}{l}\text { 自己身 } \\
\text { 体の左 } \\
\text { 右 }\end{array}$} & 吉位 & $60(3)$ & $88(7)$ & $50(2)$ \\
\hline & 仙 卧 位 & $75(6)$ & $55(6)$ & $55(6)$ \\
\hline \multirow{2}{*}{ 図 } & 力 $-\mathfrak{F} A$ & $29(5)$ & $0(0)$ & $30(6)$ \\
\hline & カ $-\boldsymbol{N}^{\prime} \mathrm{B}$ & $27(4)$ & $7(1)$ & $25(4)$ \\
\hline 形 & $n-F C$ & $31(4)$ & $7(1)$ & $53(8)$ \\
\hline 分 & カ - KD & $31(4)$ & $0(0)$ & $21(3)$ \\
\hline \multirow[t]{2}{*}{ 類 } & 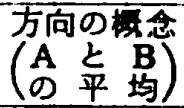 & 28 & 4 & 28 \\
\hline & 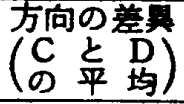 & 31 & 4 & 37 \\
\hline
\end{tabular}

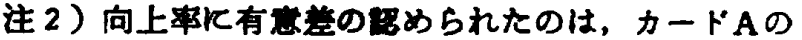

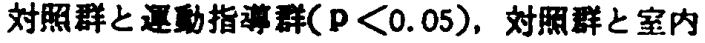
指真群 $(\mathrm{p}<0.01)$ ，力ー

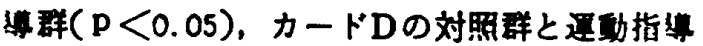
群 $(p<0.05)$ の4対である.

\%と他の項目より差が大きくなっている，室内指 導群むほとんどの項目で対照群上り高い向上事を 示しているか，仰卧位での自己身体の左台指示の 向上事は対照群より低かった。しかしながら，検 定の結果， 3 群の間の向上事の差は全項目上も有 意ではなかった。

同様に posttest 1 と 2 に関してみると，立位で の目己身体の左右指示を除いて，あとの項目は指 莩を受けた 2 群が対照群より高くなっている。 そ して，対照群と他の 2 群の向上事の間には，困形 分類のカードA（遇功指導群と $\mathrm{p}<0.05$, 室内指 道群と $\mathrm{p}<0.01$ ), カードC（室内指迤群と $\mathrm{p}<$ 0.05)，カ一ドD（運動指埒群 $\mathrm{p}<0.05 ） に$ 有意 差が認められた。

(2) 正答事について

本実験で使用されたテスト項目の团篗度贴よび その実験期間中に抠ける変化をみるために各群つ 正答事を隶めた：それを四示したのが四 $2 ， 3$ で ある，前のテストで正しく答えたにもかかわらす 後のテストで間连えたすのが若干含まれているた めに，正答事の変化は先にあげた向上事とは必ず し.主対応していない。 


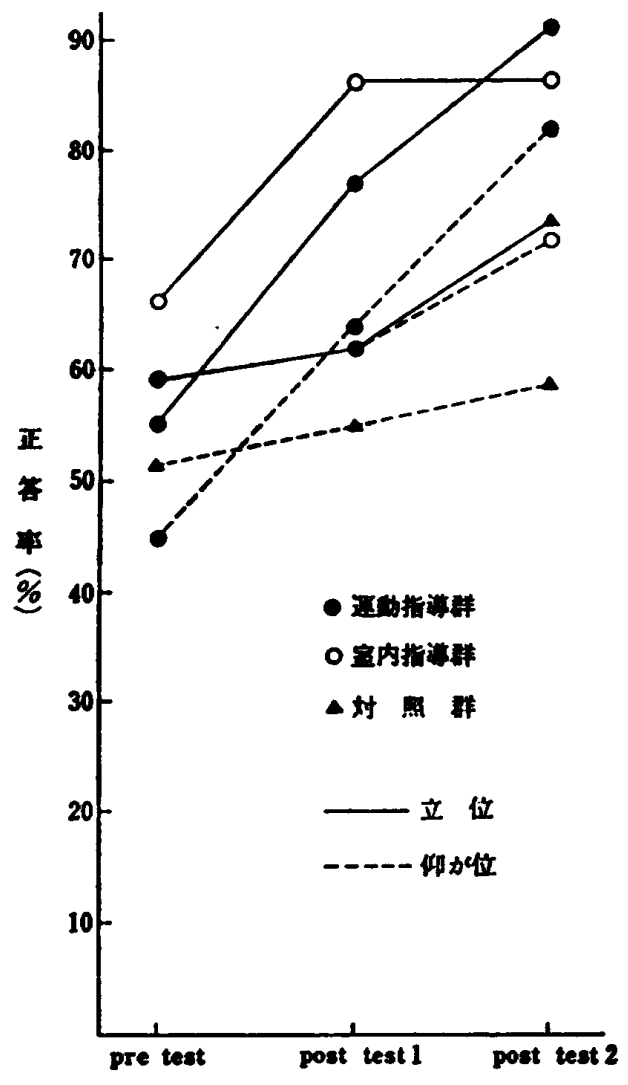

叉2 自己身体の左右指示の正答事の变化

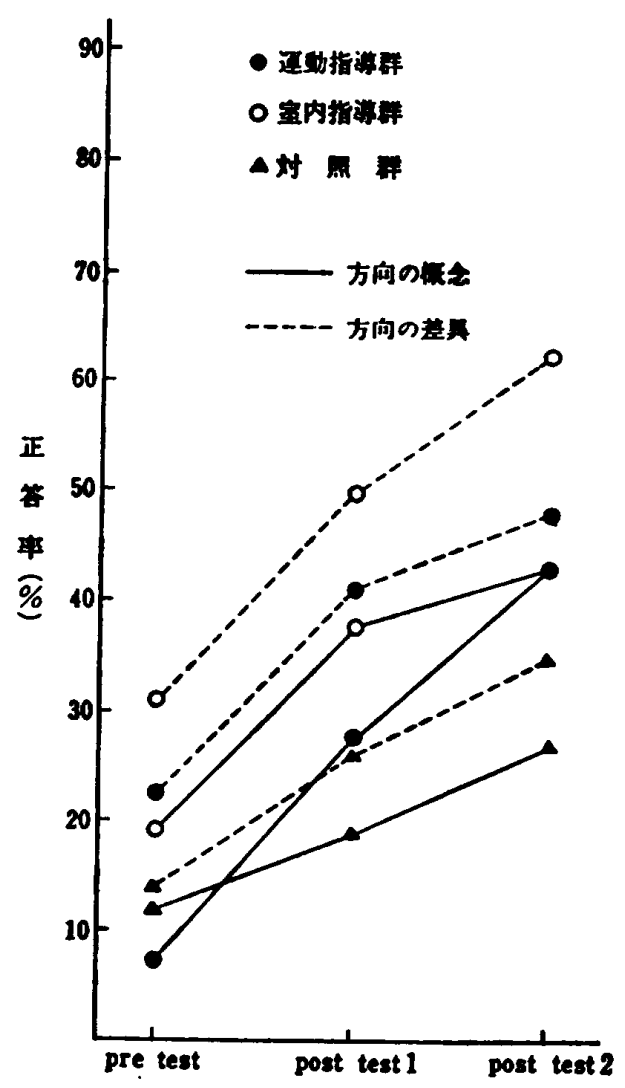

因 3 困形分類の正签率の变化
自己身体の左右指示は pretest 時の正答事がは ば50〜70\%を示し，多くの5藏児がすでに学翟し ているやさしい問題であると言える.

pretest と posttest 1 の間の各群の正答辛の変 化量について検定を行なったところ，室内指導群 では立位に氺ける自己身体の左右指示 (20\% $\mathrm{p}<$ $0.05)$, 因形分類のカードB $(24 \% \mathrm{p}<0.01)$, カ

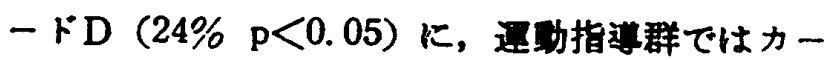
ドB $(23 \% \mathrm{p}<0.05)$ に有意な向上が呚められ た. posttes 1 と 2 の間では, 正答事の変化量に有 意のある項目はみられない。

更に，対服群と指逐を受けた 2 群の正答㖖の変 化量の差については, pretest と posttest 1 間に おける対照群 (3\%) と室内指道群 $(20 \%)$ の差 のみが有意 $(\mathrm{p}<0.05)$ であった.

(3) 結果のまとめ

指莩を受けた群の方が対照群より向上事が低い とい5煩向が1・2の項目にみられたが、これら はすへてて pretest 時における正签率の非常に高い 項目であり，両者の間に関弾のあることが示唆さ れる. また, 人形の左右指示については, pretest より posttest の項目の正答事が大きく低下する 群がみられ，テスト項目の信頼性に問題があるお のと思われる.

対展群の正答象の变化は全般的に指传を受けた 群上り小さく，指導群の何項目かが有意な正答事 の向上を示したのに対して，対照群では全項目と る有意でなかったこと，およひ，向上車るそのほ とんどが対侰群より指道を受けた群の方が大き く, 両群の向上象の差が有意である項目がみられ たことを考虑すれば，必ずしも十分大きくはない か，全体的には指望心效果か認らられたと考えて よいのではないだろらか。立た，通䵢指遭群と室 内指透群の差は注とんどないこと，指㟧の効果は

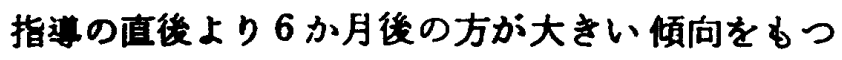
ことも指揞されよ5。

\section{考察}

奏験 I では知党还㲜的全身活功を経験するこ上 が知的能力にどのように影するかをみようとし たものであるか，結果に示したよ5に6 項目の連 功能力検査の5ち，両足連続とび越しにのみに有 
意な差が見出され，他の愐目と知能椧査の全榆査， 下位㭘榃，および性格検查の各尺度に差を見出す ことができなかったしかしこのことが知觉運 動的活功が知的能力に影帮を与えないことを示す とは必ずしいいえないであろろ。

まず,この実験でとりあけた活動にはパランス やボールを报う遇動を含んでいるが，バランスゃ ボール技能に阘する㭘查項目に差がみられず，両 足連続とび越しにのみに差がみられたよらに，远 動量(練習量)の面でみると的な身体移功の调整 活動が心になっていたことがあげられる．そし て，これらの活動は状況判断の確実さと速度，予 测の正確さなどが置功遂行上に必要であったが, 設定が実硂者の側にあり，子どもたち目身が設定 する機会がなく，また，子どすたちにとって有効 な問題解決的場面をむつ困難な水策でなかったこ ともあげられる.このことは，実賖でとりあげら れた知能検查の功作性梌查は問題解決的要类をる ち, 言語性桧查が眍情，数能力, 抽象的思考の要

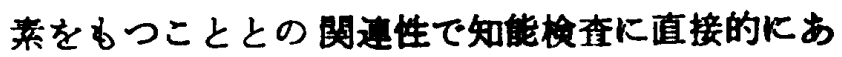
らわれなかったことが考光られよ5．また，幼児 期に知能検查や性格検㚗にあらわれる差がどのく らいの得点差によるかを考えると，特に性格検査 の場合には得点限界があらいとい5ことす指拉さ れらであろ5.12回（1回40分）の活轨经駼は年 㱓の発達差に比して耕畽は小さいことを考えなけ ればならないことと，活助が知能や性格への影 の直接性を含まないことが結果に示されていると い5ことが考えられ，知觉発䔔が的的活助に含ま れる知的能力の湅かな梌討とそれらの抽出のため の道具（㑯查）について研究が必要であることが 重要な問題である.

実余 I が直接的に知的能力に影暂する上了に場 面設定や教示が柤み込まれていなかったのに奶 し，実駼 几では知的能力のうちの左右概念を冝接 的に学習することを実䅷に組み入れ，全身远扐の 場面と保青室の場面での効果をみようとしたもの である.

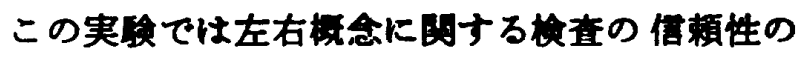
問題を含んではいるか，結果に示したよらに，対 照群との差が立位における目己身体の指示およひ カードBにおいて耐実强群に共通にみられたとい
うことと，共通性をもたなかったがカードC，D に差がられたことから，直接的な学習の意罒を むつ指迺の有効性は, 全身活功場面と非全身的活 動場面のいすれにも認められよ5。特に6か月後 の効果が大きいことは，指遭の効果とその後の経 跧との交互作用を示喛するものと思われるが，今 後の検討が必要であろ5。いずれの場面において む左在概念の学習とい5值接的指道の共通性を含 んでいるが，幼児のそれそれの場面に抖ける学習 隹度について共通するものであるかどうかが重要 な問題として考えなければならないであろう。こ の点について，全身運功の場面で指摘できること は，全身活娌そのもの（とび箱，旗くぐりなど） に興味をもち，上手にやろ5とする意欲が強くあ らわれていたといらことである。このことは，左

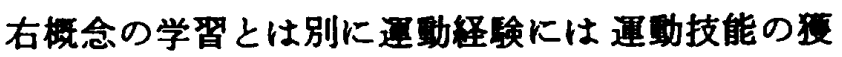
得や身体能力への刺教が同時に行なわれ，幼児に とってはむしろ後者が大きく態度にあらわれてい たといらことの利点があるといらことである.

一方, 保青室内での意四的な指導の場面では, この実硂に用いられたワークブックを材料に色を ぬることや社会事象の学習なと，手指運勁の技能 の学習を含み，幼児なりの関心をもっていたこと が指描できる，すなわち，幼児期における直接的 に意四与る学習場面は，特定の場面に限定される あのでなく，幼児の興味，関心や自発的活功場面 にどのくらい組み込めるかなどを考えることが重 要であることを示唆していると思われる.

実跧 I, 実検 IIから，全身活为の遂行の過程は 知的能力にはたらきかける内容をむつことが考え られるが，直接的，意図的に知的能力を促進させ

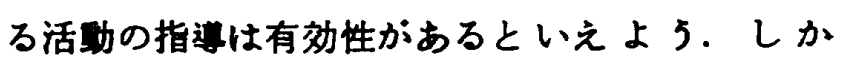
し，反面，直接的，意四的な指道を租み込まない 活娌においては，短時日に有効性を見出せるかど 5かには更に研究の必要がある.

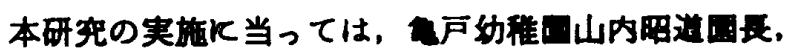

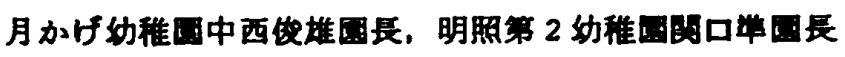
をはじめ3回の先生方には多大のご協力をいただきまし た. 深く感散いたします。

また，本研究は，昭和48-49年度科学研究党補助 金 （既题番 858012）Kよって行なわれたことを付記し ます。 


\section{文献}

1) Chasy, W.C. and Wyrick, W. : Effect of a gross motor development program on form perception skills of educable mentally retarded children. Res. Quart., 41, 354-362, 1970.

2) Corder, W.O. : Effects of physical education on the intellectual, physical and social development of educable mentally retarded boys. Excep. Child., 32, 357-364, 1966.

3) Cratty, B. J. : Active learning. PrenticeHall, 1971.

4) Cratty B. J. : Physical expressions of intelligence. Prentice-Hall, 1972.

5) Delacato, C.H. : Neurological organization and reading. C.C. Thomas, Pub., 1966.

6) Fleming, J.W.: Perceptual-motor programs, Singer, R.N.(ed), Psycho-motor domain : Movement behavior. 250-266, Lea and Febiger, 1972.

7) Frostig, M.: Movement education : Theory and practice. Follet Educational Co., 1970.

8) Harris, D.V. : Involvement in sport-A somatopsychic rationale for physical activity. Lea and Febiger, 1973.

9) Hebb, D.O.: Organization of behavior. Wiley, 1949.

10 : Humphrey, J.H. and Sullivan, D.D. : Teaching slow learners through active games. C.C. Thomas Pub., 1970.

11) Ismail, A.H.: The relationships between motor and intellectual development. Brown, R.C.Jr and Cratty, B.J. (ed), New perspectives of man in action. Prentice-Hall, 1969.

12）加驾秀夫：知能之遇功能力・技能学習.「知能の心

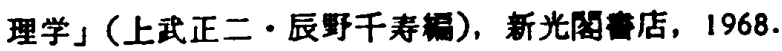

13）勝井晃：方向認知炕関与万発违的研究，風间言局，
1971.

14) Kephart, N.C.: Perceptual-motor aspects of learning disabilities. Excep. Child., 31, 201-206, 1964.

15) Knapp, B.N. : Skill in sport. Rout Ledge and Kegan Paul, 1963.

16) Leithwood, K.A. and Fowler, W. : Complex motor learning in four-year-olds. Child Developm., 42, 781-792, 1971.

17）松井三堆：体育心理学，体育の科学社，1962.

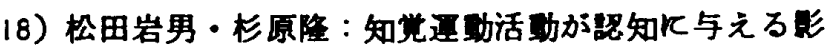
霜について，東京教育大学体育学部紀要， 12,21－27, 1973.

19) McCormick, C.C., Schnobrich, J.N., Footlik, S.W. and Poetker, B. : Improvement in reading achievement through perceptual-motor training. Res. Quart., 39, 627-633, 1968.

20) McCormick, C.C. and Schnobrich, J.N. : Perceptual-motor training and improvement in concentration in a Montessori preschool. Percept. Mot. Skills, 32, 71-77, 1971.

21) O'Connor, C.: Effects of selected physical activities upon motor performance, perceptual performance and academic achievement of first graders. Percept. Mot. Skills, 29, 703-709, 1969.

22) Oliver, J.N.:The effect of physical conditioning exercises and activities on the mental characteristics of educational sub-normal boys. Brit. J. Educ. Psychol., 28, 155-165, 1958.

23) Oxendine, J.B. : Psychology of motor learning. Appleton, 1968.

24）Piaget, J.：知能の心理学，波多野完治他訳，みす 广゙神房, 1960.

25) Singer, R.N.: Motor learning and human performance-An application to physical education skills. The Macmillan Company, 1968. 